\title{
Safeguarding and Preservation Activities at the Giant Buddhas and Other Monuments in the Bamiyan Valley 2004-2017
}

\author{
Bert Praxenthaler and Matthias Beckh
}

\begin{abstract}
The paper describes the joint missions of UNESCO and ICOMOS in Bamiyan, starting with the first investigations and initial safeguarding works at the particularly endangered Eastern Buddha niche in 2003. The problems of salvaging fragments of giant sculptures within a dangerous mix of conglomerate rock pieces, debris, and unexploded devices and the challenges of conservation works in a wartorn country are delineated. The making of the Buddhas is explained on the basis of the latest research on stone materials and loam components. Based on that, the conservation methods for sculpted conglomerate rock and the remaining parts of the loam rendering are described. Furthermore, the complex challenges of assembling a special scaffold structure within the tall niches are explicated. A variety of discussions on the reconstruction or restoration methods by international experts were slowing down the conservation process after 2013. The current state as of 2019 is a stabilized niche with the in situ remains of the Eastern Buddha statue and an installed
\end{abstract}

This article is an extended and updated version of a paper that was published following the international conference "Preserving the Cultural Heritage of Afghanistan," held at the Afghanistan Centre at Kabul University, in 2014 (Gil J. Stein e. a., (ed.) Preserving the Cultural Heritage of Afghanistan, Chicago (2017)). The following 3 years at the Western Buddha site have seen further activities on site, and developments regarding the cultural and political impact have also been noted. Matthias Beckh contributed to the chapter "Western Buddha Niche: Design and Construction of the Scaffold Structure."

Published jointly by the United Nations Educational, Scientific and Cultural Organization (UNESCO), 7, place de Fontenoy, 75007 Paris, France, the UNESCO Office in Kabul, ICON Compound, Supreme Road, Off Jalalabad Road, PD 9, Kabul, Afghanistan, and Springer Nature Switzerland AG, Gewerbestrasse 1, 6330 Cham, Switzerland.

B. Praxenthaler $(\square)$

BRR/ICOMOS, Berlin, Germany

e-mail: bert@praxenthaler.de

M. Beckh

ICOMOS, Berlin, Germany

TU Dresden, Berlin, Germany

e-mail: matthias.beckh@tu-dresden.de 
scaffold structure at the Western Buddha, waiting for the upcoming task to stabilize the instable rock surface of the niche. The paper concludes with the importance of building up local conservation capabilities and finding a consensus on future conservation missions.

Keywords Afghanistan · Bamiyan · Buddha $\cdot$ Conservation $\cdot$ Restoration · Sculpture $\cdot$ Rock $\cdot$ Stabilization $\cdot$ Scaffold

\section{Introduction}

After the destruction of the Buddhas of Bamiyan by the Taliban forces, in March 2001, and their expulsion from the region, the first international seminar on the restoration and preservation of Afghanistan's cultural heritage was held in 2002, organized by UNESCO and the Ministry of Information and Culture of Afghanistan. From July 2002, within the framework of UNESCO and as an assistance to the Afghan authorities, joint missions of UNESCO and ICOMOS were deployed to Bamiyan under the direction of Michael Petzet, then ICOMOS President (Manhart 2009a, pp. 38). The first assessments conducted on site clearly showed that immediate action was needed in order to preserve the niches and the remaining fragments of the Buddha statues (Petzet 2009a, p. 45). The international "Expert Working Group on the Preservation of the Bamiyan Site" held its first meeting in November 2002, in Munich, and has since published an annual catalogue of recommendations (Petzet 2009b, p. 54). The Cultural Landscape and Archaeological Remains of the Bamiyan Valley was put on the World Heritage List in July 2003, as well as on the List of World Heritage in Danger (Blänsdorf et al. 2009a, p. 17).

Following the first investigations and surveys, initial safeguarding works started in fall 2003 at the particularly endangered Eastern Buddha niche (Margottini 2009, pp. 175). The salvage work of the Buddha fragments could only be started in 2004, after a steel grid was installed to protect against rock fall. After the removal of fragments at both niches, restoration and safeguarding works have been carried out at the Eastern Buddha since fall 2008. The scaffold at the Western Buddha has been (in 2019) almost completed, as a preparatory measure for the stabilization of the niche.

In addition to the mission to safeguard the Buddhas, the deteriorated domed tombs of Khwaja Sabz Posh, at the entrance of the Fouladi Valley, were also restored under UNESCO's auspices (Praxenthaler 2015, pp. 250-253). A seminar on sculptures was held at an historical location that same year, with 12 participants from Bamiyan who had been employed on the revival of traditional craftsmanship methods. This seminar, a side project of dOCUMENTA(13) held in Kassel, Germany, functioned as a symbol of the revival of the art of statuary (Graham-Harrison 2012). Following the surveys of Rheinisch-Westfälische Technische Hochschule Aachen University (RWTH Aachen) and the cartography by the Délégation Archéologique Française en Afghanistan (DAFA), conservation work started at the ruins of the Shahr-e Gholghola fortified city, which had been destroyed by Genghis Khan in the thirteenth century CE. 


\section{The Giant Buddhas of Bamiyan: The Recovery of Fragments and the Consolidation of the Niches}

The two giant Buddha sculptures of Bamiyan are usually referred to as the Eastern and the Western Buddha. The Eastern Buddha has a height of $38 \mathrm{~m}$ and is slightly smaller and older than its counterpart. The Western Buddha is $56 \mathrm{~m}$ high and approximately 50 years younger than the Eastern one. Both figures were once part of a large Buddhist complex with about 700 rooms carved into the rock cliff. These rooms may have functioned as sanctuaries, cells for monks, guest houses for pilgrims, or storage rooms. The interior of these cave chambers was plastered with mud and frequently decorated with paintings or ornamental plastering (Blänsdorf et al. 2009a, p. 18).

\subsection{The Making of the Buddhas}

In order to fully comprehend the restoration work carried out at the Buddhas, it is necessary to review how they were built. Radiocarbon dates suggest that the making of the Eastern Buddha falls into the second half of the sixth century CE and that of the Western Buddha dates to the beginning of the seventh century CE (Blänsdorf et al. 2009d, p. 231-236). It is within this time frame that the Buddhas were sculpted out of the northern cliff conglomerate. This conglomerate is a typical sedimentary rock with horizontal layers of varying width, ranging from very fine grained silt to coarse-grained deposits. The most problematic aspect of those sediments is the lack of a natural binder, such as lime. The binding effect was provided by the pressure of the rock masses and embedded salt (sodium chloride). For that reason, the sediments erode very easily and are extremely sensitive to water. A piece of rock from one of the Buddha statues placed in a bucket of water will dissolve within minutes (Zou and Unold 2009, pp. 52).

The two statues endured the centuries fairly well, as they were relatively well protected inside the two niches. The mud plaster, with which these two relatively roughly carved sculptures were covered, provided additional protection. The plaster of both figures consisted of a body of clay material over which a fine layer of clay was applied. Straw-tempered mud plaster is still today the most commonly used plastering material for mudbrick buildings. The coating of the Buddhas, however, is special insofar as it did not contain straw but animal hair. To ensure that the plaster adhered to the conglomerate, Buddhist craftsmen chiseled 6-8-cm-wide round holes into the rock at the Eastern Buddha, into which a suitable stone was inserted with a fistful of mud to function as a dowel substitute. About half a century later, a different method was employed at the Western Buddha. Here, a point chisel was used to punch 4-cm-large and 7-cm-deep holes into which wooden pegs were inserted. The pegs were placed in rows along the garment folds and were connected with each other by means of a special rope material (Pfeffer et al. 2009, p. 217). The pegs were 
made predominantly from poplar, which is fairly prevalent in the region even today. Rowan and oak were used rarely (Blänsdorf et al. 2009c, p. 215). The method employed indicates that most of the garment folds of the Western Buddha were, in fact, modeled. Vincent Eyre, a British officer who served in Afghanistan, made the same observation in the mid-nineteenth century when he was held captive in Bamiyan. Eyre's description was later confirmed in greater detail by Captain Maitland (Blänsdorf et al. 2009b, pp. 201). On preserved color photographs, the Buddhas appear as ochre-colored. The research carried out by the Technical University of Munich on some hundred samples of the ca.10.000 finds of plaster fragments shows that the rendering of the Buddhas had been painted in a tempera technique, mainly in red and blue (Blänsdorf 2016, pp. 31-33), using organic binders like casein from sheep or goat milk and eggs (Lluveras-Tenorio, A. et al. 2016, pp. 43).

\subsection{The Salvage of the Fragments}

Prior to launching the salvage work, storage deposits had to be built at both Buddha sites in order to be able to store the fragments properly and to protect them from humidity. Approximately 1400 cubic meters of rubble, rock fragments, and chunks of plaster of the Western Buddha needed to be stored in dry conditions (Photo 1). The unstable composition of the conglomerate needed to be taken into consideration when carrying out the salvage work.

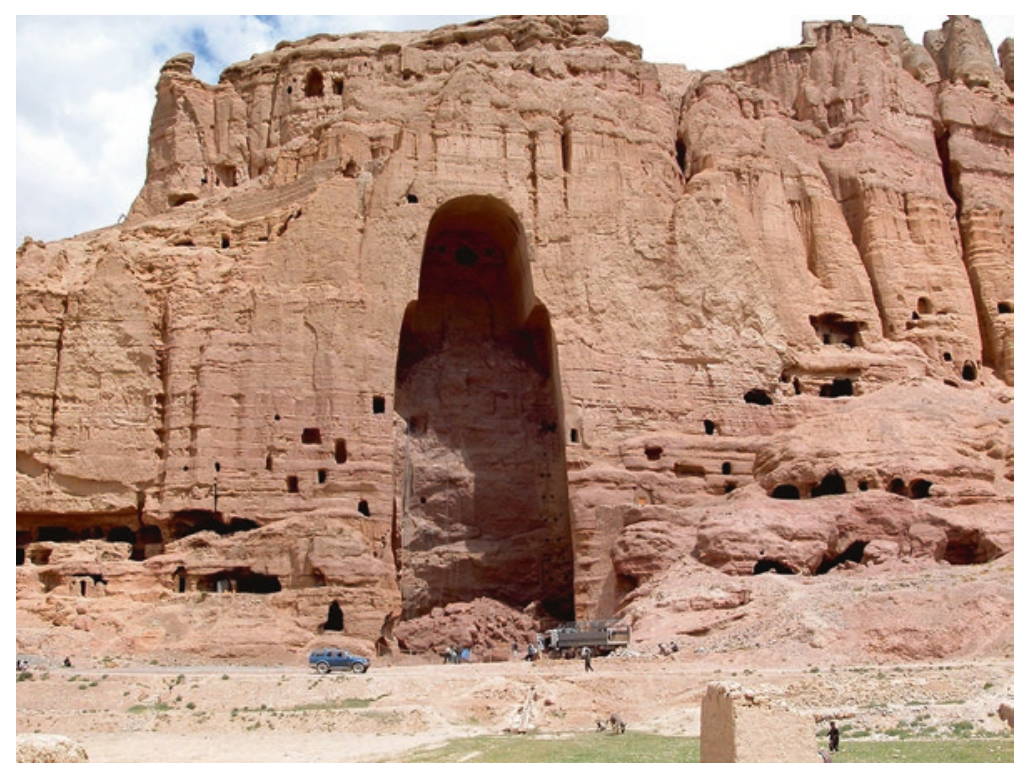

Photo 1 Western Buddha, June 2004, at the start of the mission. (@ Matthias Beckh) 


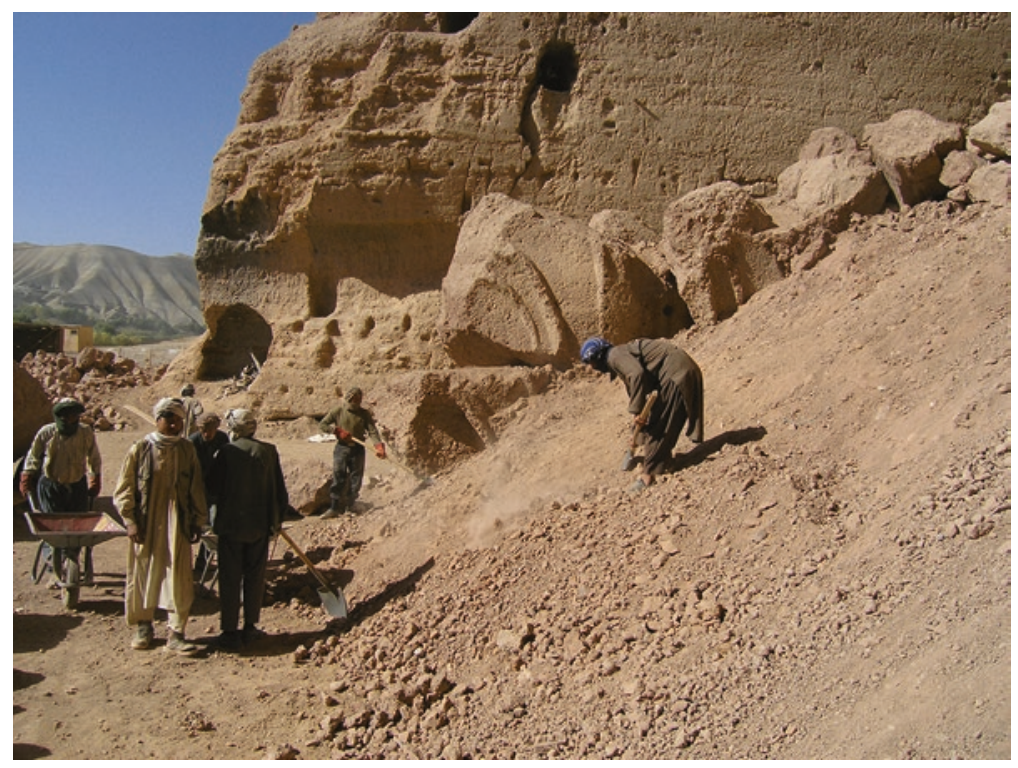

Photo 2 Western Buddha, June 2004: salvaging fragments by the Afghan team. (@ Bert Praxenthaler)

The salvage work was primarily carried out by laborers from Bamiyan using shovels and wheelbarrows (Photo 2). Wheel loaders and heavy-duty cranes were used as well, in particular to move the heavier fragments of up to 30 tons to the storage deposit. (Photo 3) An essential part of the salvage operation was the work done by the demining experts. The work sites needed to be checked on a daily basis as the rubble contained large amounts of shell splinters, other debris from explosions, and especially unexploded parts of anti-tank mines, aircraft bombs, etc. Initially, the Taliban used self-propelled guns to fire at the Buddha, yet only with limited success. Later, they piled up and detonated large amounts of explosives underneath the Buddha in order to execute their plan to destroy the statues. As a consequence, the rubble contained many exploded and unexploded parts (Praxenthaler 2009a, pp. 66).

In both niches, debris deposits were sorted according to sand, gravel, and fragments without any recognizable worked surfaces. All the pieces with recognizable worked surfaces were stored in the storage deposit, recorded on a registration form, and photographed. The large amounts of small fragments, such as chunks of plastering, wooden pecks, and ropes, which had once belonged to the plastering and surface molding, were recorded in the same fashion and temporarily stored in storage facilities of the local cultural bureau (Praxenthaler 2009b pp. 77-80). To date, restorer Edmund Melzl, who passed away in 2015, recorded approximately 10,000 fragments of the plaster coating of the figures (Blänsdorf et al. 2009b pp. 201).

While the bulk of rock fragments could be salvaged between 2004 and 2010, there are several larger rock boulders from both statues, with a weight of up to 60 to 


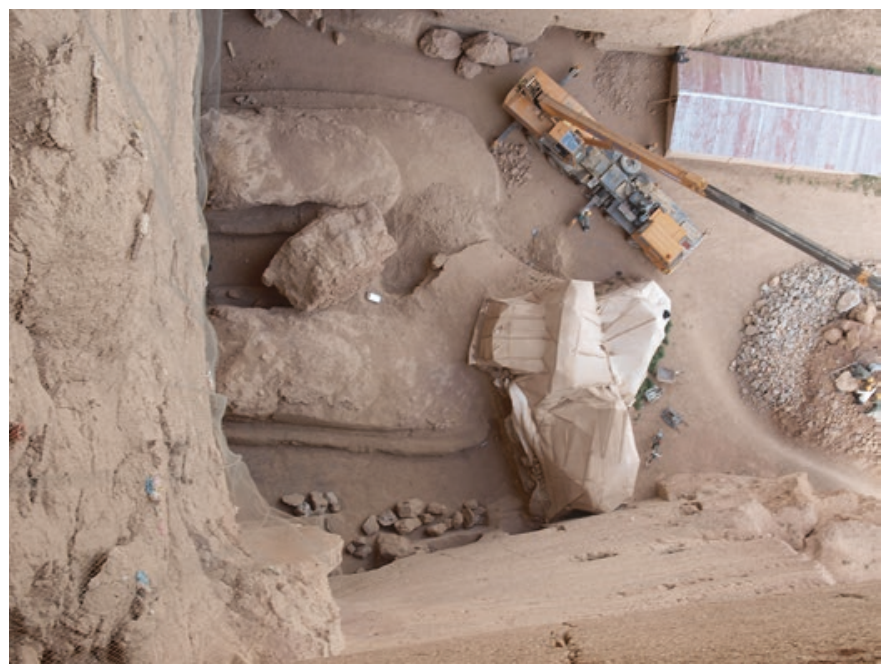

Photo 3 Western Buddha, July 2009: from top of the niche: the giant feet of the Buddha are excavated. (@) Bert Praxenthaler)

80 tons, which so far could not be lifted with the cranes available in Bamiyan. Those large fragments are still lying in front of the excavated feet of the Western Buddha and have been supplied with on-site weather protection.

\subsection{Eastern Buddha: Stabilization of the Rear Wall and Securing the In Situ Mud Plaster}

Parts of the Eastern Buddha remained intact after the detonation: parts of the right shoulder, some remains of the garment folds, and some mud plaster were still in situ, although dangerously prone to detach. The main goal was to preserve as many fragments as possible in their original location. As a scaffold could not be mounted at the time, the initial emergency safeguarding work on the clay plaster was conducted in 2004 in alpine style (Photo 4). The original mud plaster fragments that were still hanging from the wall were reached by rappelling. Rubble that had accumulated behind the somewhat detached mud plaster pieces was removed. The pieces were temporarily and reversibly secured with a punctually applied adhesion consisting of a mixture of mud, lime, and gypsum. The scaffolding could only be erected after the niche was mostly cleared, in 2008. Several of our staff members from Bamiyan, who since 2004 had gained considerable skills in the course of the clearing work of the niches, were able to expand their skill set in the field of restoration as builders, securing the still in situ mud plaster pieces. 


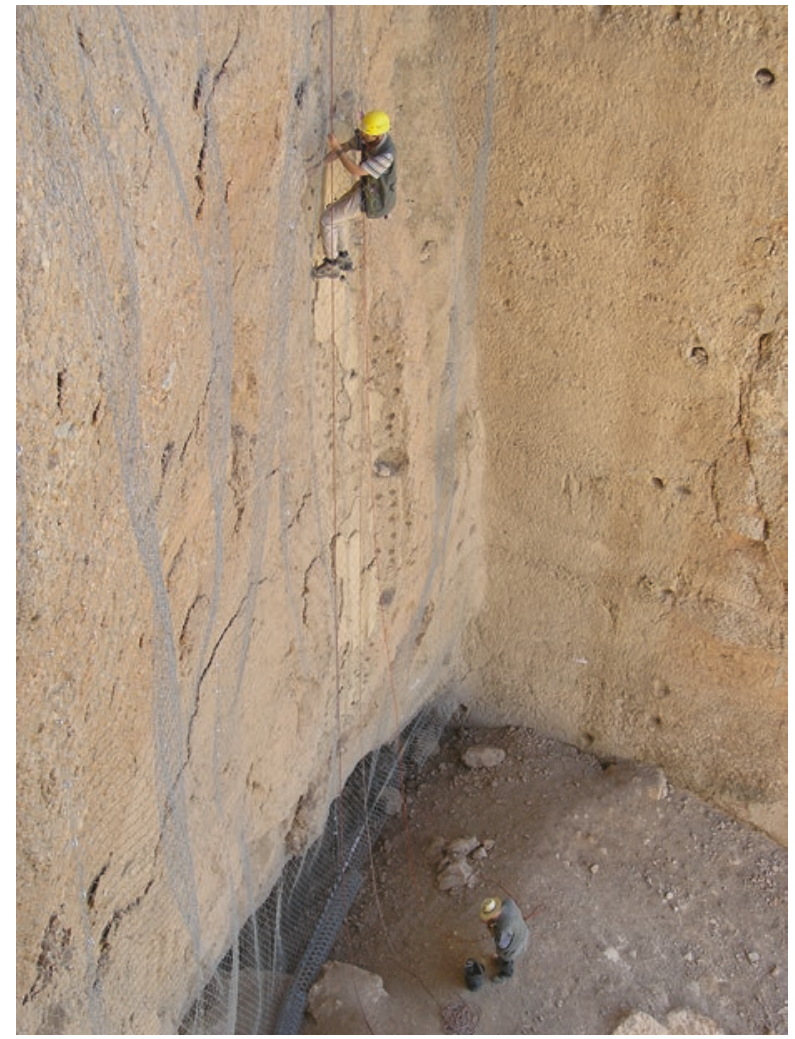

Photo 4 Eastern Buddha, July 2004: Emergency safeguarding of orginal fragments of clay plaster at the rear face of the Eastern Buddha. (@ Bert Praxenthaler)

The goal was to have most of the work carried out by the local workforce. Hence, advanced professional training in the methods and theories of restoration was an important element of the process. Based on the experience with mudbrick building and mud plaster, a mortar was developed for the consolidation of the edging, which might turn out to be suitable for the long-term stabilization of the mud plaster (Praxenthaler 2009c, pp. 137). As the core of the workforce remained essentially the same from year to year, a continuous training process was possible. Each year, the Bamiyan colleagues received a certificate describing their specific skills, which they could use to reapply the following year.

In 2008, by means of consolidating the first section of the back wall, the formerly destroyed walls of the sanctuaries behind the feet of the Eastern Buddha and a pillar in the right part of the niche could be rebuilt. Due to the destruction of the side and front walls of the temple rooms caused by the detonation, the entire block of the back wall was lacking support from below (Fecker 2009, pp. 145). The walls were rebuilt with quarry stones, in a similar fashion to the restoration conducted in the 1970s. 


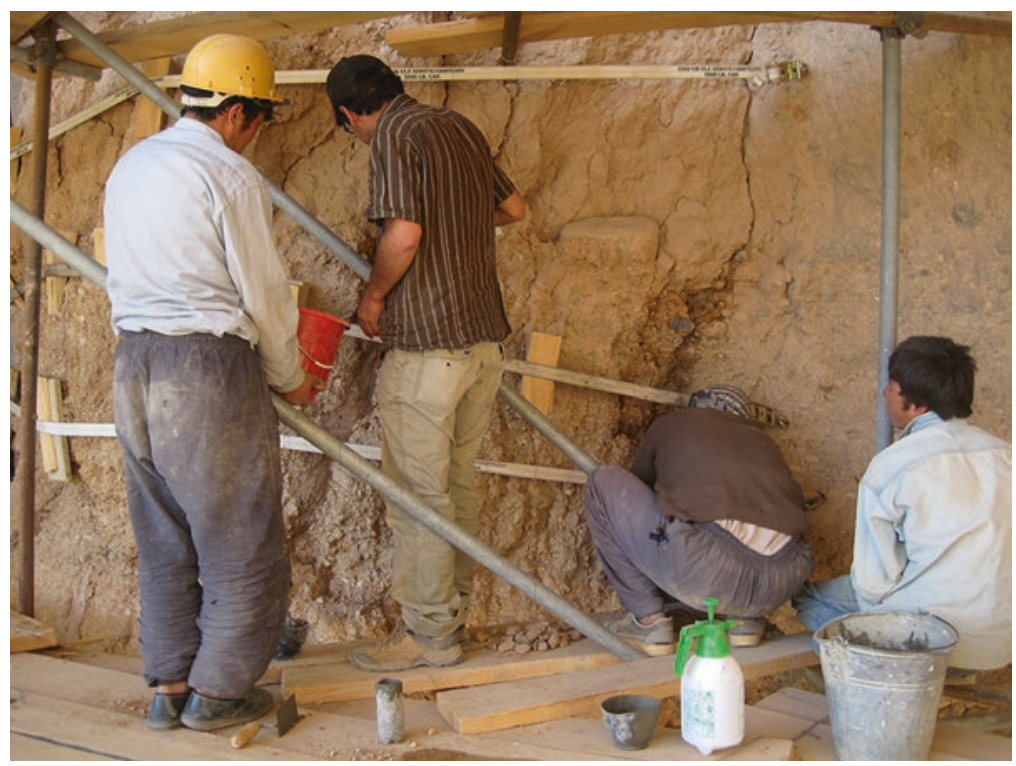

Photo 5 Eastern Buddha, October 2009: stabilising the rear face of the Eastern Buddha by Afghan team Wahab, Mujtabah Mirzai, Baba Qurban and Isa. (@ Bert Praxenthaler)

The stabilization of the back wall began in 2009, after a detailed damage assessment carried out by Fecker and Margottini. Although in a very fragile state, parts of the right shoulder, folds of the garment, and fragments of the head were still in situ. The outline of part of the left garment was also preserved. The right shoulder, in particular, is still almost completely preserved; however, the original pieces tear off easily, and at the head section, the stone fragments have separated from the back wall and shifted a couple centimeters downward. In order to preserve the silhouette of the figure (at least partly), the goal was to secure as many pieces in situ as possible. To be able to even begin with the consolidation measures, the unstable pieces needed to be secured with preliminary measures like installing steel cables and heavy-duty nylon tension belts (Photo 5).

After that, the gradual infilling of the cracks with adhesive mortar could be pursued. Using this method, the stability of the loose stone fragments could be increased day by day. After the completion of this infilling process, the needling and armature boring was done. The borings were also used to fill with mortar the gaps that could not be reached from the front. After this injection process, the long anchors could be inserted (Praxenthaler 2014, pp. 265; Photo 6). A total of 44 stainless steel anchors were needed and spread over a total area of $200 \mathrm{~m}^{2}$. The principle to preserve the remaining, albeit limited, original substance of the monument could be realized at this point.

A bonding, consisting of a mixture of Ledan-brand fresco mortar (from Italy, used particularly for frescos) and various types of mud from Bamiyan, was 
Photo 6 Eastern Buddha, July 2010: drilling the bore holes for grouting and setting anchors by Afghan team Khan Ali and Eshaq. (C Bert Praxenthaler)

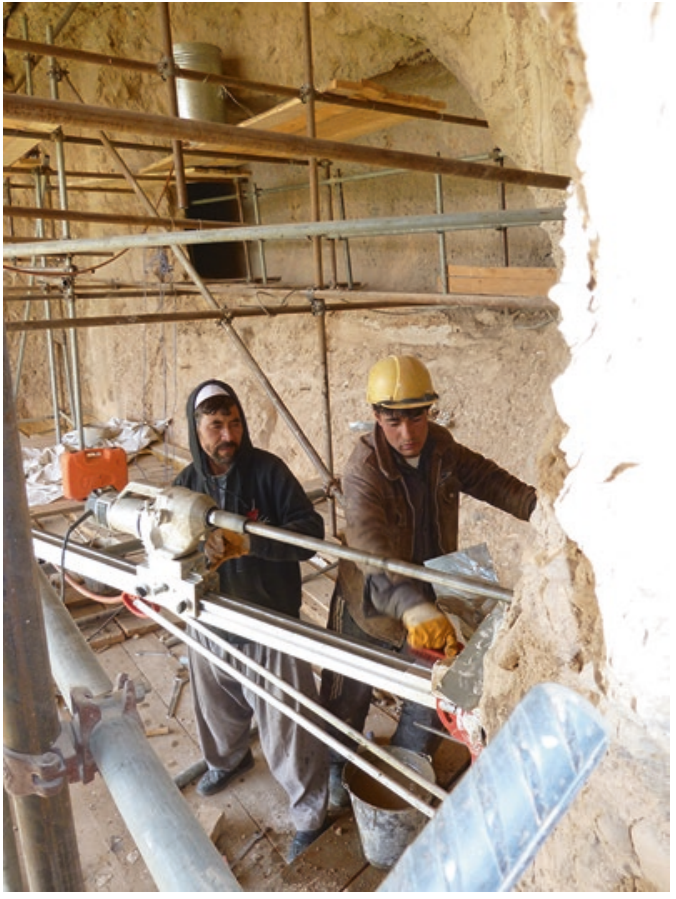

developed and tested. The consolidation of the original mud plaster was accomplished not only by means of dorsal bonding with the edging but also with needling, consisting of thin bolts of stainless steel and glass fiber.

In the course of this work, the loop path up to the head of the Buddha was also improved and protected by handrails and parapet walls. Key to the successful execution of the work was the productive teamwork between our longtime Bamiyan staff and international experts. Archeology students from Bamiyan, who were able to participate in the project as interns, and the local representatives of the Ministry of Information and Culture also contributed to the success of the mission.

The ICOMOS Advisory Mission to the Cultural Landscape and Archaeological Remains of the Bamiyan Valley (26-31 May 2014) assumed that the above works serve their purpose and that the rear wall of the Eastern Buddha could be considered stable and not prone to major collapse or rock fall (Zhan 2014, pp. 231).

Today, the completely stabilized niche of the Eastern Buddha displays on its rear side the shape of the former statue, with its conserved original remains. Additional finds of clay plaster and stone fragments are presented in the lower caves in the sense of a site interpretation center (Petzet 2016 p. 258). The site was officially opened to visitors in 2012. 


\subsection{Eastern Buddha 2013}

Other tasks, including the construction of the platform and pillars at the lower seam of the garment of the Buddha for the stabilization of the lower overhanging edge of the back wall, serving also as a protection to visitors, were executed by architect Sekandar Ozod-Seradj in consultation with Prof. Emmerling, TUM, and engineering geologist Prof. Fecker. It was not possible to complete those projects until today. Further demands during the annual Bamiyan Working Meeting in Orvieto from 10 to 11 December 2013, to discuss the conservation plan of the lower gallery and the supporting pillars, led to the mission being postponed until now (Petzet 2016 pp. 258) (Photo 7). An ICOMOS mission in May 2014 suggested to remove carefully the feet-like pillar constructions (Zhan 2014, p. 243). As the local population regarded the construction of these pillars to be the beginning of the restoration of the Eastern Buddha, the removal was not yet executable.



Photo 7 Eastern Buddha, September 2009: reconstruction of cave walls and a pillar at the lower gallery by Erwin Emmerlin, Edwin Fecker and Sekandar Seradj. (@ Bert Praxenthaler) 


\subsection{July-October 2013: Western Buddha, Safeguarding the Upper Access to the Niche}

The original access to the top area of the Western Buddha by a system of stairways similar to the situation at the Eastern Buddha is no longer possible. Such ancient access remained only partially, as most of the stairways had been eroded in the course of the last centuries. Today, the only access to the top area of the niche is made through a pathway that comes from the western slope, alongside a system of water channels, ${ }^{1}$ entering the niche by a tunnel. The damage caused by the water channels resulted in the degradation of the top entrance of the tunnel. A large boulder - the "dangerous rock" - has been washed out and was in danger of falling off the cliff from a height of about $65 \mathrm{~m}$. On top of that rock, there is a water collecting platform for the channels (Photo 8). ${ }^{2}$

In order to pre-stabilize that critical dangerous rock, steel ropes and heavy load belts were set. After cracks and fissures were grouted, boreholes for long anchors could be drilled with diamond core heads. ${ }^{3}$ This rather exposed location, with a height of $65 \mathrm{~m}$ above the ground, required a hanging scaffold construction outside the cliff with security nets. The anchors provide a cross-stabilization of the rock boulder. After the stabilization of the rock, the cause of the damage - the leaking water channels - had to be repaired. The one adjacent to the tunnel has been reconstructed by a combination of an anchored reinforced concrete foundations and stone masonry work. On top of the cliff, the damaged water collector could be repaired. In the course of that work, all adjacent water channels were also cleaned and repaired (Photo 9).

The work was accompanied by a demining action ${ }^{4}$ (Praxenthaler 2016, pp. 271). In addition to this project at the Western Buddha niche, the collected stone fragments have been regrouped in the newly built third storage building. The debris, which had been removed, was deposited at the left hand side of the niche.

\subsection{November 2014: Safeguarding and Restoration of Clay Renderings of Sanctuaries at the Western Buddha}

Due to the blasts in 2001, the sanctuaries around the niche of the Western Buddha were damaged, especially the clay rendering and stucco ornaments inside the caves. After years of cleaning the niche and the adjacent rooms, it was possible to proceed

\footnotetext{
${ }^{1}$ These water channels have been constructed in the course of the Afghan-Indian conservation mission in 1970 to prevent erosion of the front side of the cliff.

${ }^{2}$ The stabilization measures have been advised and accompaigned by Prof. Claudio Margottini.

${ }^{3}$ Three long anchors (V2A, diam- $=22 \mathrm{~mm}, 1=400 \mathrm{~cm}$ ) had been set.

${ }^{4}$ On top of the Western Buddha inside the circumambulatory EODs had been found, although three times the area had been declared cleared. The demining team removed four wired mortar shells, which most likely had been deposited at the Taliban times to cause damage for the niche of the Buddha.
} 


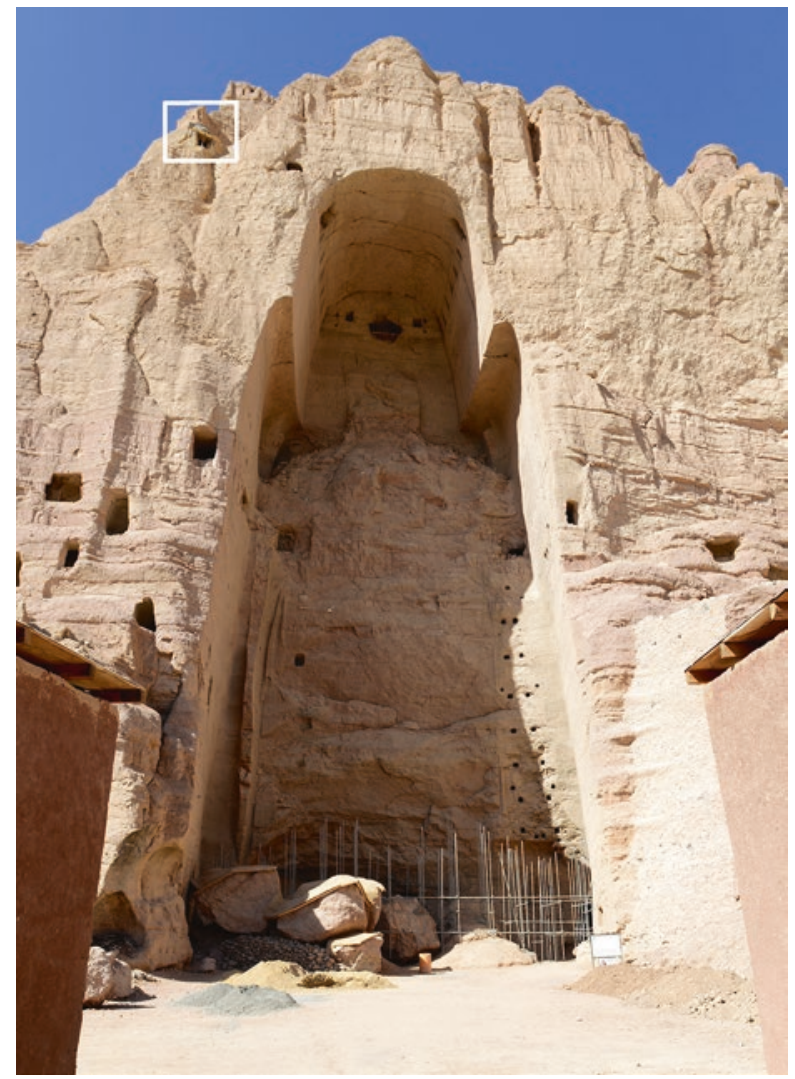

Photo 8 Western Buddha, October 2013: Safeguarding the upper access to the top of the Buddha (marked in white, top left). (@ Bert Praxenthaler)

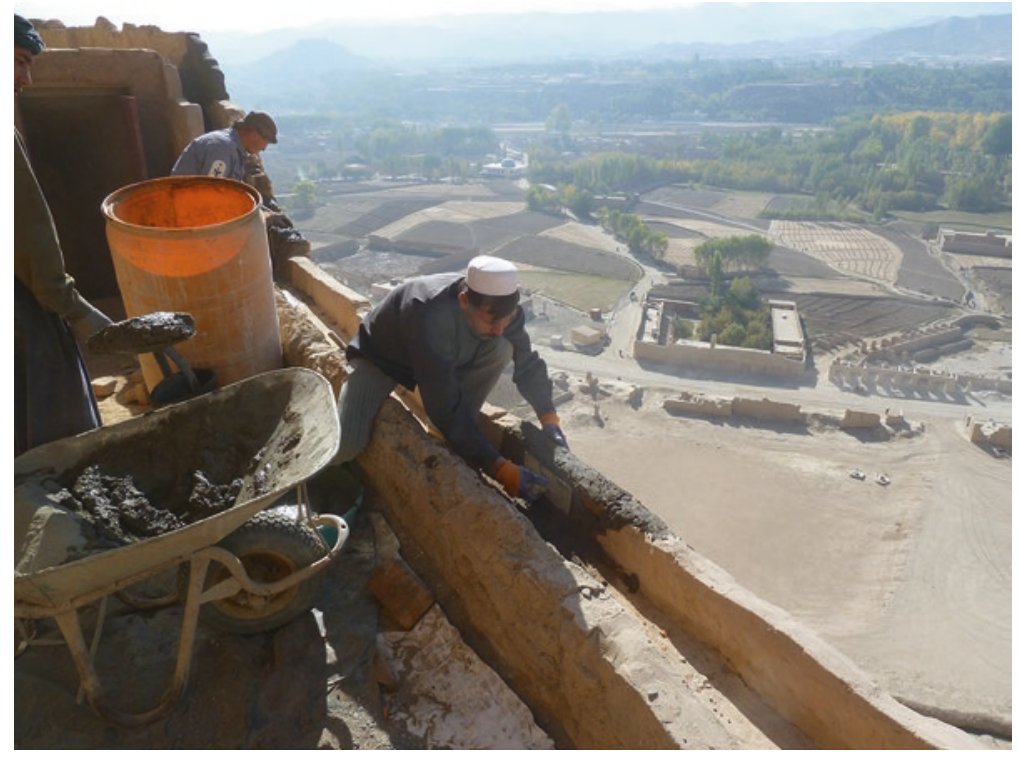

Photo 9 Western Buddha, October 2013: Repair of the water channels. (@ Bert Praxenthaler) 
with the conservation of the clay stucco, which was hanging from the walls in a precarious state.

\subsection{Western Buddha Niche: Design and Construction of the Scaffold Structure}

The conservation works at the Western Buddha niche had started in 2004. In general, the approach for the safeguarding of the Western niche followed the blueprint of the conservation works at the Eastern niche. However, due to the substantial difference in scale, the course of action proved to be much more challenging in this case. From 2004 onward, the debris within the Western Buddha niche was carefully scrutinized as mines and explosives were buried in the rubble. The stone fragments and pulverized materials were examined meticulously and sorted over the next years. All valuable materials were stored in newly erected storage shelters. The first two sheds were built in 2004 and a third one in 2009.

After the long and painstaking process of removing the debris, the niche of the Western Buddha was finally cleared and emptied in 2012. The envisioned consolidation works of the fractured rock surface of the Western Buddha niche required safe and commensurate access to the shattered rear wall. Similar to the rock conservation works previously undertaken in the smaller Eastern niche, the situation



Western Buddha niche with scaffold structure. Situation in October 2015. (@ Matthias Beckh) 
demanded a large-scale scaffold structure. The planning of the scaffold structure, which started in 2013, posed the next challenge to the project. Due to the significantly larger height and volume of the niche, the design of the scaffold structure proved to be quite demanding. The basis of the scaffold members was the highquality steel pipes that the Messerschmitt Foundation had bequeathed to the project. However, due to the sheer height and immense volume of the niche, more than twice the amount of scaffold material of the Eastern niche was required. During a site inspection in June/July, an inventory of the existing scaffold materials was compiled, and a scaffold mock-up was erected in order to obtain a better understanding of the adaptivity to uneven terrain and craggy bearing conditions.

Based on the structural assessment of the niche and the scaffold materials at hand, different scaffold options were investigated. Alternative options comprised a base structure over the full width of the niche with one-sided towers as well as a hanging platform. During a meeting in August 2013, in Munich, several options were discussed. Finally, it was decided to adopt a scheme that would in general follow the Eastern Buddha scaffold system, yet with a denser grid of vertical members to account for the greater height of the niche. The selected scaffold system was designed in August and September 2013, based on a 3D scan of the niche that was kindly provided by Sekandar Seradj. For the sake of simplicity, a column grid of $2 \mathrm{~m} \times 2 \mathrm{~m}$ was selected. In order to facilitate the arrangement of diagonal members for bracing, the floor levels were set at intervals of $2 \mathrm{~m}$ as well. The resulting spatial module of $2 \mathrm{~m}$ had already proven advantageous during the design of the Eastern Buddha scaffold. Due to the increased height, three additional rows of columns were inserted perpendicular to the rear wall to lower the axial loads in the verticals, thereby altering the grid in this area to $2 \mathrm{~m} \times 1 \mathrm{~m}$. The scaffold was attached to the adjacent rock surface of the side walls of the niche at various levels, in order to gain more horizontal stability. ${ }^{5}$

The additional pipes and couplings of Iranian origin were purchased at the local market, in Kabul. ${ }^{6}$ The assembly of the scaffold structure started in late September 2013, under the guidance of Sekandar Seradj. Soon afterward, however, the

\footnotetext{
${ }^{5}$ The scaffold itself is fastened to the anchors with steel cables. In addition, compression struts are connected horizontally to the side walls to clamp the structure tightly into the niche. At the base level, the members are resting on concrete foundation pads $(50 \mathrm{~cm} \times 50 \mathrm{~cm})$. A PE foil is installed at the bottom of the foundation to avoid any harm to the archeologically important stratum. Furthermore, the PE foil is separated from the ground with a 3-4-mm-thick geotextile. Brackets bridge the distance between the column line next to the rear wall and the rock surface. Brackets with a cantilever length of less than $1 \mathrm{~m}$ do not require additional support. Between $1 \mathrm{~m}$ and the maximum of $2 \mathrm{~m}$, an additional diagonal strut has to be added. For the structural analysis, a 3D FEM program was used. Load and design criteria followed in general the provisions of the applicable Eurocode standards. As service load, a characteristic live load of $2.0 \mathrm{KN} / \mathrm{m}^{2}$ applied evenly over one floor level of the structure was chosen. The application of wind loads and imperfections follow the regulations required by European building codes.

${ }^{6}$ Samples of the Iranian Iranbast couplings were taken to Munich and studied in the material testing laboratory of the Technische Universität München. The tests unveiled a very brittle breaking behavior of the couplings with sudden failure. The breaking behavior and the metallurgical analysis indicated the usage of cast iron, a material hardly used and unfit for the use in scaffold connections. The results mandated that the Iranbast clamps could not be used for the connections of the main load bearing members of the scaffold structure.
} 
assembly works were halted due to the controversial discussion about the undergoing consolidation works at the Eastern Buddha niche. The work finally resumed in 2015. In 2016, all missing scaffold members were installed and the inferior Iranian couplings replaced by high-quality items (Beckh 2016, pp. 293).

After securing the loose fragments in the summer of 2017, the scaffold structure now needs to be extended to the shoulder zone in order to facilitate proper access to all areas of the niche. For this purpose, the scaffold needs to bridge from the existing structure to the consolidated rock surface of the shoulder. Provisional foundations need to be casted to ensure sound support conditions for the added structural system. These foundation pads need also to be tied into the rock with steel anchors. Once the upper part of the scaffold is tightly anchored to the rock surface, it can be extended into the head area of the former Buddha. Furthermore, a construction hoist needs to be purchased and installed to lift heavier equipment to the upper stories of the scaffold (e.g., GEDA or equivalent) [GEDA is a company constructing this type of lifts; see https://www.geda.de/].

\subsection{December 2016: Geotechnical Survey and Damage and Risk Assessment of the Rear Wall of the Western Buddha Niche}

On a partially completed scaffold up to $40 \mathrm{~m}$ high and with a steel mesh on the rear wall, in November-December 2016, a geotechnical survey was performed by engineering geologist Mathias Effler, with support from students of the University of Bamiyan. The results of this survey outline the necessary consolidation and stabilization works required at the rear wall of the Western Buddha niche.

The survey also clearly pointed out the need for immediate conservation measures, as parts of the rock materials inside the niche are detached from the mountain, only resting in an unstable way. The shoulder area of the former statue is covered with large quantities of debris, which has to be removed. This debris was the source of steady stone fall in recent years.

\subsection{September 2017: Preparatory Operations at the Rear Wall of the Western Buddha Niche}

In order to complete the scaffold and to enable the start of the stabilization measures, the fragile shoulder and head zone had to be prepared. In September 2017, two professional climbers performed these temporary safeguarding measures as one of the first and most urgent priorities. ${ }^{7}$ Local working staff was employed to build provisional bridges with scaffold materials and timber to enable the removal of debris and loose material, particularly at the edges of the former shoulders of the

\footnotetext{
${ }^{7}$ Engineering geologist Mathias Effler and professional climbers Stephan Hardt and Klaus Vogt participated in the mission.
} 
Buddha. Cleaning up these areas is absolutely essential before installing the required foundations, to extend the scaffold to the shoulder area. The left shoulder and main parts of the right shoulder could be cleaned completely thanks to the dedication of the hardworking and diligent local team. The fragile detached rocks could be temporarily stabilized by steel ropes attached to newly installed anchors on either side of the former head of the Buddha (Photos 10,11).

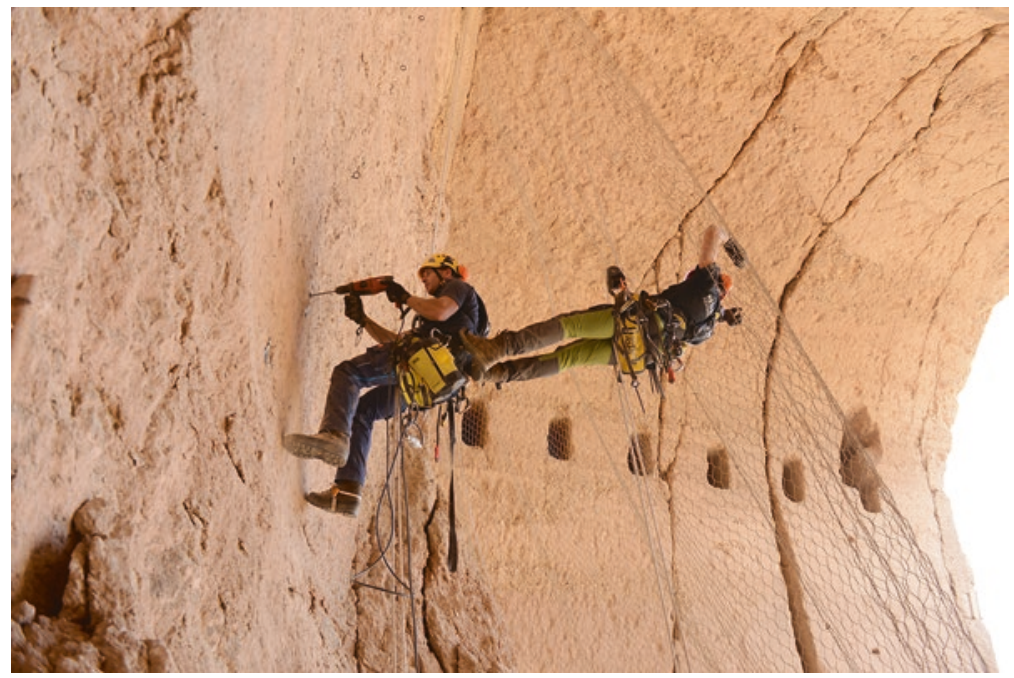

Photo 10 Western Buddha niche, September 2017: Prestabilisation measures on Western Buddha rear face, former head area (BRR-team Klaus Vogt und Stephan Hardt). (@ Bert Praxenthaler)

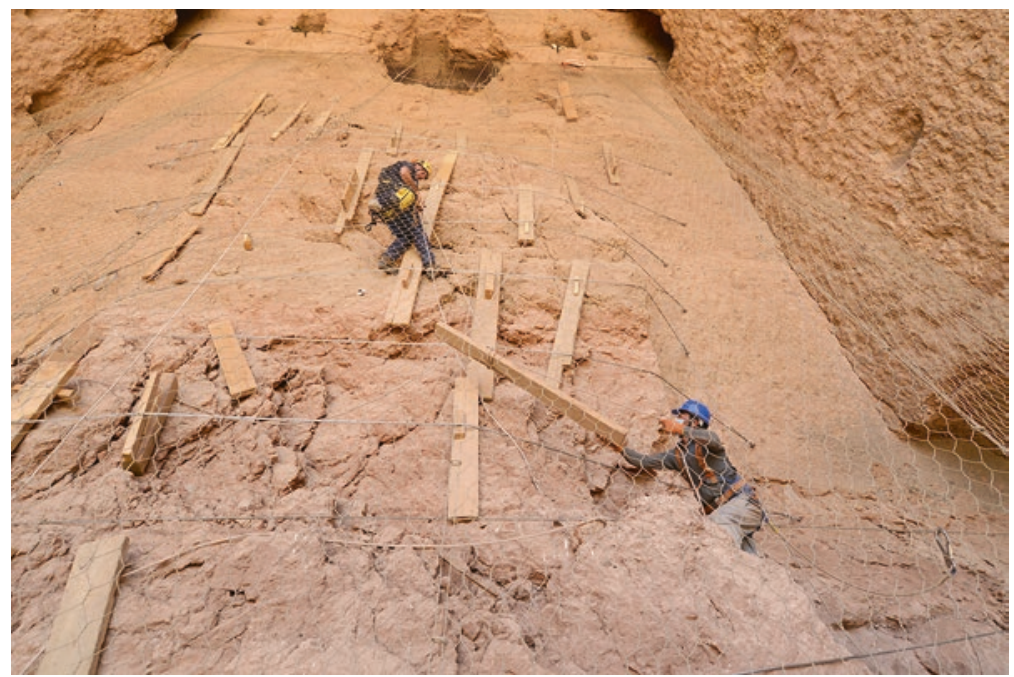

Photo 11 Western Buddha niche, September 2017: Prestabilisation measures on Western Buddha rear face, former head area (BRR-team Klaus Vogt und Haji Hossein). (@ Bert Praxenthaler) 


\section{Conclusion and Outlook}

The niches of both Giant Buddhas are now emptied from stone fragments and debris. The rear wall, the vault, and the in situ remains of the Eastern Buddha statue are stabilized, and the site is now accessible to visitors. Other tasks still to be achieved include stabilizing the rear wall and remains at the Western Buddha and stabilizing the Eastern Buddha rear wall, which can serve as a role model for the Western Giant Buddha. The collected rock fragments of both the Buddhas could also be stabilized and installed back at their original location, on the rear walls of the niches. As this is done, the temporary storage buildings in front of the niches could be dismantled.

The main positive outcome of all these missions since 2004 is the blending of the long-term experience of our Bamiyan staff with international standards and concepts on restoration and cultural heritage preservation. The combination of a longterm and stable core of local staff, the involvement of students of the Bamiyan University, and the support of the Bamiyan cultural office allowed the staff members as well as the project management to gain a high level of expertise. This allowed for developing a reliable and well-functioning framework within which the restoration tasks at Bamiyan could be carried out. As a result, many of the abovementioned projects could be carried out in a relatively short time frame and with an exceedingly high quality of craftsmanship.

Furthermore, the intense engagement of the staff members of Bamiyan with their own cultural heritage, in addition to their training over several years, led to an increased appreciation for historical and cultural values among local groups (Wyndham 2016). By integrating cultural events such as performances of traditional music and poetry readings in the restoration process, the missions were able to considerably expand their public outreach, including to representatives of the Afghan government. Ethnic and religious tensions, which were prevalent at first, lessened over time. One could go even as far as to say that working jointly on heritage projects fostered a sense of a common identity, independent of specific religious and ethnic backgrounds.

The high appreciation of Salsal and Shamama, as the people of Bamiyan used to call their Buddha statues, and the wish to have their Buddha statues back could be clearly recognized during the summer of 2015. Bamiyan had been declared the cultural capital of the SAARC states association, and the image of the Buddha became the official symbol of the festivities. A visual "reconstruction" of the Buddhas was projected for 2 days. As the Afghan government and civil society movements in Bamiyan are expressing clearly their wish for a restoration of the statues, the discussions among international experts about the future authenticity of the site continue (Wyndham 2018). So it is to hope that international experts, local cultural expertise, and civil society will soon find a common platform to develop a suitable conservation plan for the Giant Buddhas, which will pay respect to history, the authenticity of the site and the demands of the people of Afghanistan. 


\section{Bibliography}

Beckh, M. (2016). Design and partial assembly of the Western Buddha Scaffold (item 3b), 2013-2015 (p. 293).

Blänsdorf, C. (2016). New investigation of the fragments of the painted clay layers from the Buddha statues at Bamiyan, p. 26.

Blänsdorf, C. et al. (2009a). Description, History and State of Conservation before the Destruction in 2001, pp. 17-35. In Petzet, M. (Ed.) (2009), The Giant Buddhas of Bamiyan, Safeguarding the Remains. Berlin: Bässler.

Blänsdorf, C et al. (2009b). Technique of modelling the Buddha statues, pp. 201-214. In Petzet, M. (Ed.) (2009), The Giant Buddhas of Bamiyan, Safeguarding the Remains. Berlin: Bässler.

Blänsdorf, C et al. (2009c). Identification of wood species, pp. 215. In Petzet, M. (Ed.) (2009), The Giant Buddhas of Bamiyan, Safeguarding the Remains. Berlin: Bässler

Blänsdorf, C et al. (2009d). Dating of the Buddha statues - AMS 14C dating of organic materials, pp. 231-236. In Petzet, M. (Ed.) (2009), The Giant Buddhas of Bamiyan, Safeguarding the Remains. Berlin: Bässler.

Cassar, B., \& Noshadi, S. (Eds.). (2015). Keeping history alive, safeguarding cultural heritage in post conflict Afghanistan. Paris: UNESCO.

Emmerling, E., Petzet, M., (ed.). (2016). The Giant Buddhas of Bamiyan II. Safeguarding the remains, 2010-2015. Berlin: Bässler.

Fecker, E. (2009). Report on Preservation Measures of the Buddha Statues 2008, pp. 145-151.

Fecker, E. (2009) Report on Stabilization Measures in the Eastern Buddha Niche, 2009, pp. 170-174.

Graham-Harrison, E. (2012). Stone carvers defy Taliban to return to the Bamiyan valley, Guardian. 2012, May 16. http://www.theguardian.com/world/2012/may/16/ stone-carvers-taliban-bamiyan

Lluveras-Tenorio, A. et al. (2016), Analysis of binders to reconstruct the painting technique of the Western and the Eastern Buddha in the Bamiyan Valley, p. 43.

Maaß, H. (2016) Architectural survey on Shar-i-Gholghola - UNESCO Conservation Project (September/October 2014), p. 315.

Maeda, K. (2014). The Foundation of the Colossal Buddha Statues, pp. 5-13.

Manhart, C. (2009). The destruction of the Buddha statues in March 2001 and the First UNESCO Activities, pp. 37-41.

Margottini, C. (2009). The consolidation and stabilization of the Buddha Niches in Bamiyan, 2003/04; 2006, pp. 175-196.

Margottini C (ed.) (2014) After the Destruction of Giant Buddha Statues in Bamiyan (Afghanistan) in 2001. A UNESCO's emergency activity for the recovering and rehabilitation of cliff and niches. Berlin, Springer.

Martini, G. et al. (2014). The History of the Buddhas of Bamiyan, pp. 15-60.

Petzet, M. (2009a). The first ICOMOS mission to Kabul and Bamiyan (1221 July 2002) pp. 43-46. In Petzet, M. (Ed.) (2009), The Giant Buddhas of Bamiyan, safeguarding the remains. Berlin: Bässler.

Petzet, M. (2009b). Anastylosis or reconstruction - Considerations on a conservation concept for the remains of the Buddhas of Bamiyan (2002), pp. 46-51. In Petzet, M. (Ed.) (2009), The Giant Buddhas of Bamiyan, Safeguarding the Remains. Berlin: Bässler.

Petzet, M. (2016). ICOMOS Germany. Final Report of ICOMOS Germany (29 July 2014) concerning thew Pmplementation Partners Agreement no. 45002100307. In Emmerling, E., M. Petzet (Ed.) (2016), The Giant Buddhas of Bamiyan II. Safeguarding the Remains, 2010-2015, Berlin: Bässler.

Pfeffer, S. et al. (2009) p. 217. In Petzet, M. (Ed.) (2009), The Giant Buddhas of Bamiyan, Safeguarding the Remains. Berlin: Bässler.

Praxenthaler, B. (2009a). Report on Salvaging Rock fragments, 2004, pp. 66-73. In Petzet, M. (Ed.) (2009), The Giant Buddhas of Bamiyan, Safeguarding the Remains. Berlin, Bässler.

Praxenthaler, B. (2009b). Report on Salvaging Rock fragments, 2006, pp. 77-80. In Petzet, M. (Ed.) (2009), The Giant Buddhas of Bamiyan, Safeguarding the Remains. Berlin: Bässler. 
Praxenthaler, B. (2009c). Report on safeguarding of the Buddha statues, 2008, pp. 137-144. In Petzet, M. (Ed.) (2009), The Giant Buddhas of Bamiyan, Safeguarding the Remains. Berlin: Bässler.

Praxenthaler, B. (2009) Report on Salvaging Rock fragments, 2005, 86ff.

Praxenthaler, B. (2009). Report on Salvaging Rock fragments, 2007, $127 \mathrm{ff}$.

Praxenthaler, B. (2009). Report on safeguarding of the Buddha statues, 2009, $163 \mathrm{ff}$.

Praxenthaler, B. (2014). Safeguarding the Clay Plaster Remains of the Eastern Buddha Niche and the Rear Side of the Niche. In Margottini C (Ed.) After the Destruction of Giant Buddha Statues in Bamiyan (Afghanistan) in 2001 (pp. 265-283). A UNESCO's Emergency Activity for the Recovering and Rehabilitation of Cliff and Niches. Berlin: Springer.

Praxenthaler, B. (2015). The Islamic Shrines of Khoja Sabzposh: Conservation of a living religious monument in Bamiyan. In B. Cassar \& S. Noshadi (Eds.), Keeping history alive, safeguarding cultural heritage in post conflict Afghanistan (pp. 250-253). Paris: UNESCO.

Praxenthaler, B. (2016). Stabilization of the "Dangerous Rock" in the upper access of the Western Buddha Niche (item 3f ), July-October 2014, p. 271.

Praxenthaler, B. (2016). ICOMOS-Projekt Lehmstucksicherung in Kulträumen am Westlichen Buddha von Bamiyan (November 2014), p. 277.

Praxenthaler, B. (2016). Shar-i-Gholghola Conservation Project (item 3k) - ICOMOS interim report, May-July 2014, p. 299.

Praxenthaler B. (2016). Dating of Ruins at the Western slopes of Shar-i-Gholghola and the Site of Ghawarghin - AMS 14C Dating of organic Materials (October 2015), p. 331.

Praxenthaler, B. (2016) Safeguarding the Clay Plaster Remains of the Eastern Buddha Niche and the Rear Side of the Niche, pp/ 265-283.

Stein G. J e. a., (ed.). (2017). Preserving the cultural heritage of Afghanistan, Chicago.

Wyndham, C. (2016) Investigating values ascribed to cultural heritage sites in Bamiyan by residents of the Bamiyan Valley (May 2015), p. 389.

Wyndham, C. (2018). 'Bordering on the criminal': A muddle of expertise in Bamiyan, Afghanistan. https://iias.asia/sites/default/files/IIAS_NL80_3233.pdf

Zhan, W. (2016). Report on the ICOMOS advisory mission to cultural landscape and archaeological remains of the Bamiyan Valley (26-31 May 2014), p. 225.

Zou, Y., \& Unold, F. (2009). First considerations on the stability of the Buddha Niches and their stone material, $52 \mathrm{ff}$.

The opinions expressed in this chapter are those of the author(s) and do not necessarily reflect the views of the UNESCO, its Board of Directors, or the countries they represent.

Open Access This chapter is licensed under the terms of the Creative Commons AttributionShareAlike 3.0 IGO License (https://creativecommons.org/licenses/by-sa/3.0/igo/), which permits use, sharing, adaptation, distribution, and reproduction in any medium or format, as long as you give appropriate credit to UNESCO, provide a link to the Creative Commons licence and indicate if changes were made. If you remix, transform, or build upon this chapter or a part thereof, you must distribute your contributions under the same licence as the original. This publication is also available at the UNESCO Open Access Repository: https://unesdoc.unesco.org/

The designations employed and the presentation of material throughout this publication do not imply the expression of any opinion whatsoever on the part of UNESCO concerning the legal status of any country, territory, city or area or of its authorities, or the delimitation of its frontiers or boundaries.

The authors are responsible for the choice and the presentation of the facts contained in this chapter and for the opinions expressed therein, which are not necessarily those of UNESCO and do not commit the Organization.

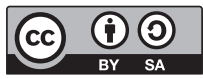

